\title{
İNSAN HAKLARININ SAĞLANMASINDA TEMEL BİR SORUNSAL OLARAK DEMOKRASI
}

\author{
DOI: $10.33717 /$ deuhfd.567625
}

\section{Dr. Ö̆̆r. Üyesi Celal YEŞILLCAYIR*}

\begin{abstract}
$\ddot{O}_{\mathbf{z}}$
Insan hakları ile demokrasi arasında vazgeçilmez bir ilişkinin olduğuna dair öteden beri yaygın bir kanaat söz konusudur. Öyle ki kamuoyunda insan hakları ve demokrasinin sıklıkla bir arada kullanılan iki kavram oldukları görülmektedir. Diğer taraftan demokratik ülkelerin insan haklarına aykirı tutumlar içinde bulundukları dikkat çekmektedir. Buna göre insan haklarının belirlediği eşitlik anlayışı ile demokrasinin benimsediği eşitlik anlayışı arasında temel bir farklılık olduğu anlaşılmaktadır. Mezkûr farklllı̆̆ın temellerinin felsefi bağlamda analiz edilmesi sorunun aydınlatılması bakımından önem arz etmektedir. Sorunun temellerinin aydınlatılması ile birlikte insan hakları ile demokrasi ilişkisinde yaşanan sorunların giderilmesi adına bazı çözüm önerilerine ulaşmak mümkün olacaktır.
\end{abstract}

\section{Anahtar Kelimeler \\ İnsan Hakları, Demokrasi, Doğal Hak, Birey, Kitle Hâkimiyeti, Çoğunluk \\ DEMOCRACY AS AN ESSENTIAL PROBLEMATIC FOR ENSURING OF HUMAN RIGHTS}

\begin{abstract}
There has been an opinion that there is an indispensable relationship between human rights and democracy all along. So, it seems that both concepts humand rights and democracy frequently are used together in public opinion.

Gümüşhane Üniversitesi Edebiyat Fakültesi, Felsefe Bölümü, Sistematik Felsefe ve Mantık Anabilim Dalı Öğretim Üyesi (e-posta: cyesilcayir@gumushane.edu.tr) (ORCID: 0000-0002-3132-920X) (Makalenin Geliş Tarihi: 19.03.2019) (Makalenin Hakemlere Gönderim Tarihleri: 21.03.2019-15.04.2019/Makale Kabul Tarihleri: 15.05.2019-13.05.2019)
\end{abstract}

Dokuz Eylül Üniversitesi Hukuk Fakültesi Dergisi, Cilt: 21, Sayı: 1, 2019, s. 333-351 
Hovewer, attitudes against human rights by democratic countries draw attention. From this point of view, we can infer from understanding of equalities, formed by human rights and democracy that there is a fundamental difference. Analyzing of bases of aforementioned difference in the context of philosophy are significant so as to enlighten the problematic. Through enlightening the bases of the problem, it could be possible to suggest some solution proposals in order to overcoming the problems in the relationship of human rights and democracy.

\section{Keywords}

Human Rights, Democracy, Natural Right, Individual, Mass Domination, Majority 


\section{GİRIŞ}

İnsan Hakları Evrensel Bildirgesi'nin (İHEB) ilan edilmesinin üzerinden yetmiş yılı aşkın bir zaman geçmesine rağmen, insan hakları ihlallerinin dünyanın dört bir tarafında eskiden olduğu gibi devam ettiği dikkat çekmektedir ${ }^{1}$. XX. Yüzyıl'ın sonlarında Bosna ve Srebrenitsa' da yaşanan soykırımlar yakın tarihte yaşanan insan hakları ihlalinin en bariz örneğidir. Günümüzde ise Akdeniz'de alabora olan sığınmacı tekneleri, kıyılara vuran ve kaybolan cesetler ${ }^{2}$ adeta İHEB'in yetmişinci yılının sorgulanması gerektiğine işaret etmektedir. Bununla birlikte küresel anlamda yaşanan insan hakları ihlallerini temel bir paradoks olarak nitelendirmek gerekmektedir. Çünkü dünya kamuoyunda bir taraftan insan hakları söylemleri artarken, diğer taraftan da hak ihlalleri hız kesmeden devam etmektedir. Şu halde dünya genelinde insan hakları anlayışı ve bu anlayışın hayata geçirilmesi hususunda belirgin sorunların yaşandığı yadsınamaz bir gerçektir.

İnsan hakları sorunlarının/paradoksunun nedenlerinin anlaşılması bağlamında felsefenin eleştirel ve analitik özelliği önemli katkılar sağlayacak mahiyettedir. Elinizdeki çalışmada yaşanan insan hakları sorunları insan hakları ve demokrasi ilişkisi bağlamında ele alınmaktadır. Bu çerçevede temel olarak demokrasilerin insan haklarının sağlanmasında bozucu bir etki yapıp yapmadığının irdelenmesi amaçlamaktadır. Araştırmamız kapsamında öncelikle insan haklarının hayata geçmesi bakımından demokrasinin elzem bir anlayış olduğunu savunan görüşler muhtasar olarak serimlenmektedir. İkinci adımda ise insan hakları ile demokrasi arasında vazgeçilmez olduğu düşünülen ilişkinin/bağın mahiyeti farklı örnekleme ve analizlerle tartışmaya açılacaktır. Bu çerçevede insan hakları konusu demokratik yönetim anlay1şını benimseyen ülkeler bağlamında ele alınmasının yanında, mezkûr ülkelerin başka ülkelerle olan ilişkileri çerçevesinde de soruşturulacaktır. Son tahlilde ise insan haklarının sağlanmasında demokrasinin hangi sorunlara yol açabileceğine dair bazı tespitler somutlaştırılarak, sorunların giderilmesine yönelik felsefi bağlamda bazı çözüm önerilerine ulaşılmaya çalışılacaktır.

Konu ile ilgili mevcut literatür incelendiğinde insan hakları ve demokrasi ilişkisi bağlamında temel olarak iki türlü tartışmanın yer aldığı görül-

1 Gosepath, Stefan: "Universalität der Menschenrechte - Ein Erklärungsansatz", Gelten Menschenrechte universal? Begründungen und Infragestellungen, ed. Günter Nooke, Georg Lohmann, Gerhard Wahlers, Herder, Freiburg 2008, s. 195.

2 Yeşilçayır, Celal: "Sı ̆̆ınmacılar Hakkındaki Ön Kabulleri Belirleyen Etmenler Üzerine Eleştirel Bir Değerlendirme”, Kutadgubilig Felsefe-Bilim Araştırmaları, 32, 2016, s. 122. 
mektedir. Birinci grupta yer alanlar insan haklarının sağlanması için demokrasinin vazgeçilmez olduğunu savunurken, ikinci gruptakiler daha ziyade demokrasi ile insan haklarının birbirleri ile ilişkilendirilmesinin çok doğru bir anlayış olmadığı görüşündedirler. İnsan haklarının sağlanmasında demokrasilerin vazgeçilmez olduğunu savunan görüşler öteden beri yaygın olarak kabul gören bir anlayıştır. Ancak demokrasilerin insan haklarının sağlanmasında nasıl bozucu bir etkisinin olabileceği akademik/entelektüel açıdan yeteri kadar ele alınmadığı görüldüğünden çalışmamızda ağırlıklı olarak demokrasinin insan haklarının sağlanmasındaki bozucu etkisi irdelenmektedir. Söz konusu düşünceleri tahlil etmeye insan hakları ve demokrasi kavramlarının anlamları üzerinde durarak başlamamız yerinde bir tutum olacaktır:

Felsefenin temel özelliklerinden biri de kavramların temellerine inerek özüne uygun bir biçimde ifade etmektir ${ }^{3}$. İnsan hakları ve demokrasi kavramlarının özüne uygun olarak aydınlatılması her iki anlayış arasında kurulan ilişkinin anlaşılması bakımından önem arz etmektedir. İnsan hakları her türlü etnik köken, ten rengi, cinsiyet, din ve mezhep gibi farklı özelliklerin ötesinde salt insan olmaya bağlı haklardır. Öyle ki bütün diğer özellikleri öne çıkarılmaksızın, dünyaya insan olarak gelmek, insan haklarına sahip olmak için yeterli bir nedendir ${ }^{4}$. Buna göre insan hakları, pozitif hukuk yasalarının tanıdığı haklar değildirler, bilakis salt insan olmaya bağlı doğal haklardır. Demokrasi ise Yunanca bir kavramdır ve demos (halk, çoğunluk) ile kratos (güç, iktidar) sözcüklerinin birleştirilmesi suretiyle oluşmuştur5. Buna göre demokrasinin genel kabul gören anlamı ise halkın yönetimi ya da halk yönetimi şeklindedir. Buradaki temel ölçüt ise halkın çoğunluğunun belirlediği bir hükümetin ülke yönetiminde yer almasının meşru olarak kabul edilmesidir. Araştırmamız çerçevesinde insan hakları kavramı, belirtildiği gibi, salt insan olmaya dayalı haklar olarak, demokrasi kavramı ise siyasi bir yönetim biçimi olarak ele alınacaktır. Demokrasi konusunda ortaya çıkmış sosyal demokrasi, liberal demokrasi vb. tanımların/anlamların tartışması araştırmamız kapsamında yer almamaktadır.

İnsan hakları ve demokrasi kavramlarının asli anlamlarına değindikten sonra mezkûr kavramlar/anlayışlar arasında kurulan ilişkiyi iki farklı bakış

3 Kuçuradi, İoanna: İnsan Hakları: Kavramları ve Sorunları, Türkiye Felsefe Kurumu, Ankara 2016, s. 1.

4 Yeşilçayır, Celal: “İnsan Haklarının Aydınlatılmasında Felsefi Bilginin Önemi”, Kaygı, Uludağ Üniversitesi Fen-Edebiyat Fakültesi Felsefe Dergisi, 31/2, 2018, s. 247.

5 Çüçen, A. Kadir: İnsan Hakları, Sentez Yay., Ankara, 2013, s. 170. 
açısından analiz etmemiz gerekmektedir. İnsan hakları ve demokrasi ilişkisi öncelikle aralarında vazgeçilmez bir bağın olduğunu savunanların görüşlerine yer vererek tartışılmaya girişilecektir. İnsan hakları hususunda küresel anlamda yaşanan sorunlara yer verildikten sonra araştırmamızın da temel konusunu oluşturan insan haklarının sağlanmasında demokrasinin nasıl bir sorun teşkil edebileceği tartışılmaya çalışılacaktır.

\section{INSAN HAKLARININ SAĞLANMASI BAKIMINDAN DEMOKRASI}

Demokrasinin insan haklarının hayata geçmesi bakımından en uygun siyasi rejim olduğuna dair yaygın bir kanaat mevcuttur. Siyasi düşünce tarihi incelendiğinde insan hakları kavramının gelişimi ile modern demokrasilerin gelişimi arasında sıkı bir bağın olduğu ileri sürülmektedir ${ }^{6}$. Benzer biçimde insan hakları ile ilgili kaleme alınan birçok yazıda insan hakları ile demokrasi arasında sıkı bir bağın kurulmaya çalışıldığı dikkat çekmektedir. Söz gelimi Robert Alexy, ulusal devletlerde insan haklarının sağlanmasına en uygun yönetim şeklinin demokrasi olduğunu ileri sürmektedir ${ }^{7}$. Erhan Atiker'e göre insan hakları meselesinin aslında bir demokratikleşme talebinden kaynaklandığı kuşku götürmez bir gerçektir ${ }^{8}$. A. Kadir Çüçen ise insan haklarının en iyi biçimde demokratik yönetim şekline sahip toplumlarda hayata geçtiğini savunmaktadır". Aynı zamanda "demokrasi ve insan hakları" adı altında okul müfredatlarında bazı dersler yer almaktadır. Söz konusu derslerde okutulmak üzere birçok ders kitabının kaleme alındığ 1 görülmektedir ${ }^{10}$. Bununla birlikte insan hakları ile demokrasi arasında niçin sıkı bir bağın kurulduğuna dair bir soru akıllara gelmektedir:

Tarihsel olarak insan hakları anlayışının belgelerde yer almasının demokrasi bilincinin gelişmesi ile başladığı görülmektedir ${ }^{11}$. İnsan hakları ile

6 Can, Nevzat: Siyaset Felsefesi Problemleri, Elis Yay., Ankara 2005, s. 285.

Alexy, Robert: "Die Institutionalisierung der Menschenrechte im demokratischen Verfassungsstaat", Philosophie der Menschenrechte, ed. Stefan Gosepath, Georg Lohmann, Suhrkamp Verlag, Frankfurt am Main 1998, s. 244.

8 Atiker, Erhan: "İnsan Hakları Üzerine... Bir Yöntem Denemesi”, Sosyoloji Dergisi, 3/5, 1999, s. 93 .

9 Çüçen, s. 53.

10 Ders kitaplarına bazı örnekler: Tüzün, Günsu: Ortaöğretim Demokrasi ve İnsan Hakları Ders Kitabı, Ada Matbaacılık, Ankara 2018; Üçbaş, Tevfik: Demokrasi ve İnsan Hakları Liseler İçin Ders Kitabı, Fil Yayınevi, İstanbul 2010.

11 Erdoğan Tosun, Gülgün: "Birleştirici Demokrasi Devlet-Sivil Toplum İlișkisinin Yeniden Yapılandırılması İçin Bir Aracı Olabilir mi?”, Sivil Toplum ve Demokrasi, ed. Lütfi Sunar, Kaknüs Yayınları, İstanbul 2005, s. 43. 
demokrasi arasında kurulan söz konusu sıkı bağın oluşmasında demokrasilerin temel olarak bireylerin/yurttaşların iradesine dayalı bir yönetim anlayışını meşru sayması önemli bir etkendir. Başka bir deyişle günümüz dünyasında insan haklarının sağlanmasının yolunun demokrasiden geçtiği anlayışı demokratik devletlerin bireylerin ve toplumun kanaatlerini dikkate almalarına dayanmaktadır ${ }^{12}$. Şu halde demokrasi dışındaki birçok rejimde güçlüler ve siyasal elitlerin hâkimiyeti söz konusuyken, demokratik yönetimlerde yurttaşların yönetimi belirleme hakkı söz konusudur ${ }^{13}$. Dolayısıyla monarşiler ve krallıklardaki gibi tek kişinin yönetim anlayışı karşısında demokratik rejimler, ülkenin yönetilmesi hususunda halkın tercihini meşru olarak gördüklerinden insan hakları ile demokrasi arasında sıkı bir bağın kurulmasının olağan hale geldiği anlaşılmaktadır.

Görebildiğimiz kadarıyla insan haklarının sağlanması için demokratik yönetimlerin elzem olduğu anlayışı yaygındır. Yurttaşların düşüncelerini ve onların oyları ile belirlenen hükümetleri meşru gören demokrasilerin insan haklarının sağlanması bakımından öteki rejimlerle kıyaslandığında çok daha yetkin/uygun bir sistem olduğu anlaşılmaktadır. Bununla birlikte insan hakları ile demokrasi arasında kurulan ve vazgeçilmez olduğu düşünülen mezkûr rabıtanın çok da sağlıklı olmadığını düşünenler de yok değildir. Şu halde demokrasi ile yönetilen ülkeler ilk bakışta insan haklarının sağlanması için en uygun mecra olarak görülebilirler. Ancak her iki anlayışın temelleri ve insan hayatına uygulanışı etraflıca irdelendiğinde aslında iddia edildiği gibi sağlıklı bir demokrasi-insan hakları ilişkisinin olmadığını ileri süren fikirler de ortaya çıkmıştır.

\section{INSAN HAKLARININ SAĞLANMASI BAKIMINDAN DEMOKRASI SORUNSALI}

Evrensel Bildirge'nin (İHEB) ilanının üzerinden yetmiş yıl geçmesine rağmen nerdeyse her gün dünyanın değişik yerlerinden insan haklarının ihlallerine dair haberlere rastlanmaktadır. Bunlardan savaş ve çatışmaların yol açtığ 1 kıtlık, açlık, katliam ve sığınmacılık durumları başlıca hak ihlalleri olarak dikkat çekmektedir. Birçok insan hakları ihlallerinin yaşandığı dünyamızda demokrasi ile insan hakları arasında nasıl bir bağın mevcut olduğu irdelendiğinde oldukça düşündürücü durumların yaşandığı dikkat çekmek-

12 Bingöl, Orhan: “70. Yıldönümünde İnsan Haklarını Yeniden Düşünmek”, Mavi Atlas, Çağdaş Felsefe Tartışmaları Özel Sayısı, Aralık 2018, s. 72.

13 Touraine, Alain: Demokrasi Nedir?, çev. Olcay Kunal, Yapı Kredi Yayınları, İstanbul 2002, s. 100. 
tedir. Bu bağlamda insan hakları ile demokrasi ilişkisini (A. Demokratik Ülkeler Bağlamında İnsan Hakları B. Demokratik Ülkelerin Diğer Ülkelerle İlişkileri Bağlamında İnsan Hakları olmak üzere) iki kategoride analiz etmeye çalışalım.

\section{A. Demokratik Ülkeler Bağlamında İnsan Hakları}

Bir Afrika ülkesinde yapılan seçimlerle ilgili anlatılan bir anekdot demokrasi adına önemli bir fikir vermektedir: "Oy verme kulübelerinde demokrasi pupa yelken gidiyordu. Bir adam karılarını getirmediği için azarlanıyor. "Gelmek istemediler" - "Onları dövmeliydin". Pek çok Dowayo’ya ne konuda oy kullandıklarını sordum. Boş gözlerle baktılar bana. Kimlik cüzdanımızı aldık, orada duran görevliye verdik, o da mühürledi, böylece de oyumuz işaretlendi, diye cevap verdiler. Evet, ama niçin oy kullanıyorlardı? [...] Hiçbiri seçimlerin ne için yapıldığını bilmiyordu"14. Bu örnek demokratik yönetime geçmiş bir ülkede birden fazla karısı olan ve onları oy kullanmadıkları için dövmesi istenen adamdan söz edilmesinin yanında insanların niçin oy kullandıklarına dair bilinçten oldukça uzak oldukları da anlaşılmaktadır. Ancak politik anlamda demokrasinin sağlanmasına rağmen birçok insan hakları ihlalinin yaşanması mümkündür. Çünkü demokratik yönetimlerde siyasi partiler seçim dönemlerinde yurttaşların daha fazla oyuna alabilmek adına insan hakları ile uyuşmayan çalışmalar ve vaatlerle ortaya çıkabilmektedir.

Almanya'da Nazi Partisinin iktidara gelmesi bu türden demokratik bir anlayışa verilebilecek belirgin bir örnektir. Hitler, seçim dönemlerinde salt Almanlığa dayalı ve refah bir ülke vaat ederek, halkın oyunun önemli bir kısmını alarak iktidarı elde etmiştir. Ancak bu dönemlerde, başta toplama kampları (KZ) olmak üzere, işlenen insan hakları ihlalleri tarihte eşine az rastlanır türdendir. Dolayısıyla siyasi rejimin demokratik olarak işlediği birçok ülkede insan hakları ihlallerinin yaşanmadığını iddia etmek oldukça zor görünmektedir ${ }^{15}$. Buna göre siyasi bir rejim olarak demokrasi, yukarda üzerinde durulduğu gibi, insan haklarını sağlamaya uygun siyasi bir rejim olmakla birlikte, söz konusu haklara zarar verici bir özelliği de içinde barındırmaktadır. Şu halde bazı ülkelerde çoğunluğu memnun edip, onların oylarını almak uğruna, azınlıkların hakları görmezden gelinerek, insan hakları ihlalleri işlenebilmektedir. Ronald Dworkin'e göre sayı olarak çoğunluğu

14 Tomasevski, Katarina: Development Aid and Human Rights Revisited, Pinter, New York 1993, s. 15. Aktaran: Kuçuradi, s. 187.

15 Kuçuradi, s. 186, 187. 
elde etmeyi meşru gören demokratik anlayışlar çoğunluğun istedikleri gerçekleştirilmeye çalışılırken, azınlığın hakları önemsenmeyecektir/ görmezden gelinecektir ${ }^{16}$. Buna göre demokratik yönetimlerde esas olan insan haklarının sağlanmasından ziyade demokratik anlayışın hayat bulmasıdır. Başka bir ifadeyle çoğunluğun belirlediği bir partinin iktidara gelmesi ve çoğunluğun aldığı kararların uygulanması demokratik olmakla birlikte insan haklarının gerçekleştiği anlamına gelmemektedir.

Bununla birlikte insan hakları ihlallerinin yalnızca dünyanın geri kalmış bölgelerinde değil, ekonomisini geliştirmiş ve ileri demokratik rejim olarak nitelendirilen bölgelerinde de yaşandığı dikkat çekmektedir. Söz gelimi Amerika Birleşik Devletleri'nin (ABD) elli eyaletinin otuz sekizinde verilen idam cezaları bunun en bariz örneklerinden biridir. Özellikle Texas, California ve Florida'da verilen cezaların çoğu siyah tenli erkeklere yönelik olduğu belirlenmiştir. Bunun yanında ABD'de çocuk yaşta olanların ve zihinsel özürlülerin idamının arttığı dikkat çekmektedir. Dolayısıyla dünyanın ileri demokrasisine sahip olduğu düşünülen bir ülkede insan haklarının temelini oluşturan ilkelerden yaşama hakkının ihlali oldukça çarpıcı bir durum olarak karşımıza çıkmaktadır. Aynı zamanda yetmiş yıl önce İnsan Hakları Evrensel Beyannamesinin ilan edilmesine öncülük eden bir ülkede bu derecede insan hakları ihlallerinin yaşanması oldukça düşündürücü bir durumdur ${ }^{17} . \mathrm{Bu}$ noktada demokrasi ile yönetilen ülkelerde insan hakları ihlallerinin yaşanmasının en önemli nedeni nedir? diye bir soru akıllara gelmektedir.

Kanaatimize göre demokratik yönetimlerin çoğulcu katılımcı anlayışı temel bir meşruiyet kaynağı olarak görmesinden kaynaklanan insan hakları ihlalleri ortaya çıkmaktadır. Bu anlayışta devlet haklarının insan haklarının üstünde görülmesi nedeniyle insan hakları hususunda önemli derecede ihtilaller yaşanabilmektedir. Aynı zamanda devlet, siyasi düzenin korunması adına insan haklarının sınırlandırılmasına yönelik kamuoyu oluşturarak, hakları ihlal eden kararlar alabilmektedir ${ }^{18}$. Şu halde demokrasi bir ülkede çoğunluğun karar verdiği bir iktidarın yönetimi olarak düşünüldüğünde

16 Dworkin, Ronald: "Freiheit, Selbstregierung und der Wille des Volkes", Philosophie der Menschenrechte, ed. Stefan Gosepath, Georg Lohmann, Suhrkamp Verlag, Frankfurt am Main 1998, s. 299.

17 Hamm, Brigitte: Menschenrechte, Ein Grundlagenbuch, Springer Verlag, Opladen 2003, s. 11.

18 Özek, Çetin: “İnsan Hakları Kavramında Yeni Anlayış ve Sınırlamalar”, İstanbul Üniversitesi Hukuk Fakültesi Mecmuas1, 60/1-2, 2002, s. 137. 
bireysel haklar ve özgürlükler için bir tehdit unsuru haline gelebilmektedir. Çünkü (mutlak) monarşi rejimlerinde tek kişide olan iktidar, demokrasi ile birlikte toplumun belli bir çoğunluğunun eline geçmiş bulunmaktadır. Diğer bir ifadeyle tek kişinin hâkimiyeti belli bir kitle hâkimiyetine (mass domination) dönüşmüştür ve bu durumda bireysel haklardan ziyade iktidarı belirleyen kitlenin talepleri önemsenecektir. Bu durumu halkın hâkimiyeti anlamına gelen demokrasi ile insan hakları arasındaki bir paradoks olarak nitelendirmek yerinde bir tutum olacaktır ${ }^{19}$. Mustafa Erdoğan'a göre söz konusu paradoksun nedeni bütün çekiciliğine rağmen demokrasinin içeriğindedir. Çünkü demokrasi çoğunluğun iradesini hedeflemesine karşın ayrilıklar, bölünmeler ve çekişmeler üzerine kurulu bir rejimdir. Bu bağlamda etnik, dinsel ve bölgesel bölünmeler ise demokrasilerde karşılaşılan en büyük sorunlardır ${ }^{20}$. Dolayısıyla demokratik rejimlerde halkın çoğunluğunun ülkenin yönetimini belirlemesi ile birlikte insan haklarının sağlandığını iddia etmenin oldukça zor olduğu anlaşılmaktadır. Söz konusu sorunsalın temel nedeni ise demokrasilerin çoğunluğun belirlediği hükümetleri meşru olarak kabul etmeleri ve buna bağlı olarak toplumsal anlamda gruplaşmaların/bölünmelerin ortaya çıkmasıdır.

Bununla birlikte demokrasinin mahiyetini oluşturan eşitlik anlayışı ile insan haklarını belirleyen eşitlik anlayışının birbirinden farklı ögeler olduğu anlaşılmaktadır. Çünkü insan haklarında tek tek bütün bireylerin eşitliği esas alınırken, demokrasiler halkın çoğunluğu tarafından belirlenen bir eşitliği meşru olarak görmektedirler. Dworkin'e göre halkın çoğunluğunu önemseyen demokrasiler insan haklarının sağlanmasının değil, belki de sağlanamamasının temel nedenidirler. Çünkü çoğunluğun iradesinin gerçekleşmesi insan haklarının sağlandığı anlamına gelmemektedir. Bir toplumda iradesi ve hakları görmezden gelinen azınlıklar demokratik anlamda çok fazla sorun teşkil etmemekle birlikte insan haklarının hayata geçmediğinin temel göstergesi olacaktır ${ }^{21}$. Buna göre devletin ortaya çıkmasından/oluşmasından bağımsız olarak salt insan olmaya bağlı hakları demokratik bir anlayışla özdeşleştirmek oldukça tartışmalı bir durum kazanmaktadır. Diğer bir ifadeyle insan haklarının sağlanmasını demokrasinin sağlanmasına bağlamak içinde önemli açmazları barındıran bir tutum olarak karşımıza çıkmaktadır. Dolayısıyla demokratik devletlerin halkın çoğunluğunun tercihini ülke yöne-

19 Menke, Christoph/Pollmann, Arnd: Philosophie der Menschenrechte zur Einführung, Junius Verlag, Hamburg 2007, s. 172-174.

20 Erdoğan, Mustafa: Anayasal Demokrasi, Siyasal Kitabevi, Ankara 2004, s. 253.

21 Dworkin, s. 294-296. 
timi olarak meşru olarak görmelerinden kaynaklanan insan hakları ihlalleri yaşandığı anlaşılmaktadır.

Görebildiğimiz kadarıla insan hakları ve demokrasi mahiyeti gereği birbirinden iki ayrı unsura işaret ettiklerinden, iki anlayışın da kavramsal olarak birbiriyle çok fazla ilişkilendirilmesinden kaynaklanan sorunlar yaşanmaktadır. Ernst-Wolfgang Böckenförde'ye göre demokrasi devletin iradesinin halk oylamasına bağlı olan yönetim sistemleri ile ilgili politik bir düzeni ifade ettiğinden, bu kavramın insan hakları ile birebir uyuştuğunu iddia etmek her şeyden önce bir kavram kargaşasına yol açması kaçınılmazdır. İnsan hakları salt insan olmaya bağlı olan ve meşruiyeti insan onuruna dayalı haklar iken, demokratik sistemde meşruiyet halkın tercihine bağlıdır ${ }^{22}$. Bununla birlikte insan hakları kavramının özüne uygun bir biçimde aydınlatılamamasından/tanımlanamamasından kaynaklanan birçok insan hakları ihlalleri yaşandığ 1 vakıadır ${ }^{23}$. O halde insan hakları tanımlanırken her türlü sosyo-kültürel şartlardan, politik sistemlerden, cinsiyet ve etnik kökenden bağımsız olarak salt insan olmaya bağlı evrensel haklar olduğunu gözden kaçırılmaması gerekmektedir. Bununla birlikte insan haklarının evrenselliğine karşın, demokrasi bir yönetim şekli olarak, uygulandığı devlete göre geçerliliğe sahip olan hukuk sistemi ile yakından ilişkilidir. Dolayısıyla demokrasiler çoğunluğun iradesini meşru görmesinin yanında uygulandığı devletin politik şartlarına göre de değişiklik içereceğinden dolayı insan haklarının evrenselliği anlayışı ile uyuşmamaktadır. Çünkü politik sistemler kendi önceliklerini gerçekleştirmek çabası içindedirler ve seçimlerde yurttaşların oylarına talip olduklarından halkın çoğunluğunun faydasını gözetmeyi amaçlarlar. Demokrasinin çerçevesi bunu gerçekleştirmek için uygun bir mecradır. Buna göre demokrasi ve insan haklarının birbiriyle sıkı bir ilişki içinde olduğu tezinin açmazları giderek belirgin bir hal almaktadır.

Söz konusu uyuşmazlığı bariz bir biçimde göz önünde seren diğer bir husus ise demokrasilerin evrensel etik ilkelerden ziyade mevcut ülkedeki mutabakatı meşru bir zemin olarak görmeleridir. Öyle ki mahiyeti gereği demokrasiler meşruiyetini konsensüs/uzlaşma üzerinden sağlamaktadır ve seçimler de halkın oyları üzerinden bir konsensüs oluşturmak üzere

22 Böckenförde, Ernst-Wolfgang: "Ist Demokratie eine notwendige Forderung der Menschenrechte?", Philosophie der Menschenrechte, ed. Stefan Gosepath, Georg Lohmann, Suhrkamp Verlag, Frankfurt am Main 1998, s. 236.

23 Tepe, Harun: "Sosyal Haklar ve İnsan Hakları: Sosyal ve Ekonomik Haklar Olmadan İnsan Hakları Korunabilir mi?”, Uluslararası Sosyal Haklar Sempozyumu Bildiriler, ed. Nergiz Mütevellioğlu, Mehmet Zanbak, Belediye-İş, Ankara 2009, s. 97-101. 
yapılmaktadır. Albrecht Wellmer'e göre özü itibarıyla adaletsiz/haksız (ungerecht) olan hususlar üzerinde de konsensüs oluşturmak da mümkündür. Dolayısıyla demokratik olup da, hak ihlali olabilecek birçok durumla karş1laşılabilir. Buna göre demokratik sistemler/meclisler Nazi suçlularının ve vergi kaçıranların beraat edeceğine, sı ğınmacıların sınır dışı edileceğine, kürtaj yaptıran kadınların ve protestocuların cezalandırılacağına dair kararlar alabilirler $^{24}$. Çünkü mevcut yapı içindeki oy çokluğunu ve mutabakatı meşru/legal bir ölçüt sayan bir anlayıştan genel geçer etik ilkeleri dikkate alması beklenemez. Bu durum aynı zamanda kamuoyunda yaygın olarak kullanılan "Demokrasilerde çare tükenmez" sözünün neden yaygınlaştığına dair bir fikir de vermektedir. Çünkü demokratik anlayışlar evrensel ilkeleri kendi sistemlerine uydurmak maksatlı, yorumlama hakkını meşru olarak görmektedirler.

\section{B. Demokratik Ülkelerin Diğer Ülkelerle İlişkileri Bağlamında İnsan Hakları}

İnsan haklarının sağlanması bakımından demokrasinin vazgeçilmez bir rejim olduğunu savunan anlayışların yanında demokrasilerin söz konusu hakların sağlanmasında nasıl bozucu etki yapabileceğini tartışmaya çalıştık. Bununla birlikte insan hakları-demokrasi ilişkisini uluslararası boyutuyla anlayabilmek içim demokratik yönetim anlayışını benimseyen ülkelerin diğer ülkelerle ilişkilerini ele almamız yerinde bir tutum olacaktır. Önceki bölümde demokratik bir yönetim anlayışına rağmen ABD'de uygulanan idam cezalarına değindik. Bununla birlikte bu ülkede yaşanan insan hakları ihlallerini yalnızca bir iç mesele olarak sınırlandırılmaması gerekmektedir. ABD'nin dünyanın başka bölgelerine yönelik tutumu da birçok insan hakları ihlaline yol açmaktadır. Söz konusu sorunsalı bazı örneklemelerle serimlemeye çalışalım:

$\mathrm{Bu}$ çerçevede öncelikle ABD’nin "demokratikleştirme" adı altında Afganistan ve Irak'1 işgal etmesinin ve binlerce insanın bu süre zarfında hayatını kaybetmesinin insan hakları ile pek uyuşmadığını ifade etmemiz gerekmektedir $^{25}$. Hatta ABD, 2003 yılında Birleşmiş Milletler insani müdahale ilkesini de çiğnemiştir. O sıralar ABD Başkanı olan George W. Bush,

24 Wellmer, Albrecht: "Menschenrechte und Demokratie", Philosophie der Menschenrechte, ed. Stefan Gosepath, Georg Lohmann, Suhrkamp Verlag, Frankfurt am Main 1998, s. 272.

25 Geis, Anna: "Diagnose: Doppelbefund - Ursache ungeklärt? Die Kontroverse um den demokratischen Frieden”, Politische Vierteljahresschrift, 42 (2), 2001, s. 282-298. 
Irak'a yönelik savaş kararı alıp almamaları konusunda Birleşmiş Milletlerin onayına gerek duymadıklarını, karar verdikleri şeyi gerçekleştireceklerini ifade etmiştir ${ }^{26}$. Söz konusu işgallerle birlikte demokratik olmayan ülkelere demokrasi getirmeyi amaçladıklarını iddia etmektedirler. Ancak belli bir ülkeyi demokratikleştirme maksadıyla başvurulan, savaş ve işgaller bariz bir biçimde insan hakları ihlallerine yol açmaktadır ${ }^{27}$. İşgal ve savaşlar nedeniyle insanların hayatını yitirmesi insan haklarının yaşama ilkesi bağlamında düşünüldügünde kabul edilebilir bir durum değildir. Bununla birlikte işgal ve savaşların yol açtığı sığınmacılık sorunsalı küresel anlamda ciddi boyutlara ulaşmış durumdadır.

Savaş, tecrit ve tehdit gibi insan hayatını doğrudan etkileyen olumsuz şartlar nedeniyle birçok insan doğup büyüdüğü yeri terk etmek zorunda kalmaktadır. Bernd Ladwig'e göre sığınma arayışı içinde olan insanların büyük riskleri göze alarak zorlu yolculuklara çıkmalarının nedeni, yaşadıkları yerlerdeki hayat şartlarının güçlüğüdür. Ancak demokratik yönetimlere sahip batılı ülkeler savaşlar ve işgaller nedeniyle oldukça zor durumda kalmış bu insanlar için vicdanlı davranmaktan oldukça uzaktır ${ }^{28}$. Sığınmacılara yönelik Alman Havalimanlarında sınır polisleri tarafından uygulanan işkence uygulandığ 1 dikkat çekmektedir ${ }^{29}$. Sözgelimi geçen yıl Almanya'nın sınır dışı ettiği Afgan bir sığınmacının intihar etmesi ${ }^{30}$ üzerine insan haklarının temelini oluşturan yaşama hakkı ilkesi demokratik ülkeler özelinde tartışılmaya başlanmıştır.

Diğer taraftan demokrasi ile yönetilen ülkelerde de gizli diplomasi ve politikaların yürütüldüğü ortaya çıkmaktadır. Özellikle Julian Assange tarafından 2006 yılında wikiLeaks belgelerinin yayımlanması ile birlikte ABD'nin küresel anlamda tasarladığ 1 birçok gizli plan deşifre edilmeye başlanmışıır' ${ }^{31}$. Bununla birlikte Edward Snowden tarafından ABD Ulusal

26 Fox, Gregory H.: Humanitarian Occupation, Cambridge University Press, Cambridge 2008, s. 185.

27 Yeşilçayır, Celal: Ebedi Barış, Pax Romadana Birleşmiş Milletlere, Tezkire Yay., İstanbul 2017, s. 81.

28 Ladwig, Bernd: “Offene Grenzen Als Gebot Der Gerechtigkeit?”, Migration Und Ethik, ed.. Andreas Cassee, Anna Goppel, Mentis Verlag, Münster 2012, s. 68.

29 Hamm, s. 11.

30 Sirleschtov, Antje/Monath, Hans/Woratschka, Rainer: "Seehofer bedauert Suizid von abgeschobenem Afghanen": https://www.tagesspiegel.de/politik/asylpolitik-seehoferbedauert-suizid-von-abgeschobenem-afghanen/22789716.html, Erişim Tarihi: 01.03.2019.

31 Nida-Rümelin, Julian: "Demokratie will Öffentlichkeit", Die Zeit, 16.12.2010: http://www.zeit.de/2010/51/Wikileaks/komplettansicht, Erişim Tarihi: 01.03.2019. 
Güvenlik Dairesi'nin (NSA) dünya genelinde bazı internet sayfaları ve epostalar vasitasıyla birçok kişinin özel bilgilerini elde etmesi deşifre edilmiştir $^{32}$. Dünya kamuoyunda ileri seviyede bir demokrasi ile yönetildiğine inanılan ABD'nin dünyanın başka ülkelerine yönelik yürüttüğü gizli politika $^{33}$ açıkçası birçok ülkeyi güvenlik bakımından rahatsız/tedirgin etmektedir. Söz konusu gizli politikaların nelere yol açabileceği hususunda Kant'ın düşüncelerine kulak vermek gerekmektedir. O, özellikle uluslararası diplomasilerde/politikalarda şeffaflığın olmamasını bir hak ihlali olarak nitelendirmektedir. Ona göre insanlar ve ülkeler şeffaflık prensibine uyulması etik ve hukuki bakımından elzemdir ${ }^{34}$. Aynı zamanda o, ülkelerin dünyanın herhangi bir yerinde yaşanan hak ihlalinin (Rechtsverletzung) gizli kalmamas1 için uluslararası politikada şeffaflık prensibine önem vermektedir ${ }^{35}$. Dolayısıyla Kant'ın düşünceleri bağlamında küresel anlamda yürütülen gizli diplomasiler önemli bir savaş nedenidir. Dünya üzerinde savaşların sona ermesi, insan hakları ve barışın gelişebilmesi için gizli diplomasilerden uzak durulması ve şeffaflık prensibine uyulması gerekmektedir.

Görebildiğimiz kadarıyla demokrasiyle yönetilen ülkelerin başka ülkelere yönelik tutumlarında insan haklarına riayet ettiklerini ileri sürmek oldukça zor görünmektedir. Dolayısıyla demokrasi ile yönetilen ülkelerin kendi içlerinde insan hakları ile ilgili sorunlar yaşanabildiği gibi, başka ülkelere yönelik insan haklarını ihlal edici tutumlara yöneldikleri de yadsınamaz bir gerçek olarak karşımıza çıkmaktadır. Buraya kadar yapmaya çalıştığımız analizlere göre ilk bakışta insan haklarının sağlanmasında en uygun siyasi rejimin demokrasi olduğu görüşü öne çıkmaktadır. Ancak birçok ülke demokratik bir siyasi anlayışı benimsemesine rağmen insan hakları ile uyuşmayan tutumları meşru görebilmektedir. Yapılan analizlere istinaden insan hakları ile demokrasi arasında kurulmaya çalışılan yaygın anlayışın ciddi anlamda tartışmalı bir hal aldığını iddia edebiliriz. Bu durumu, insan hakları ile demokrasi arasındaki bir paradoks, açmaz ya da çelişki olarak nitelendirmemiz mümkündür. Aynı zamanda bu durum Derrida'nın da üzerinde

32 Greenwald, Glenn: Saklanacak Yer Yok, çev. Türkan Çolak, Profil Yay., İstanbul 2015, s. 331-338.

33 ABD'nin söz konusu açığa çıkarılmış gizli politikalarının yanında PKK gibi terör örgütlerine aleni olarak lojistik ve silah desteği vermesi başka bir sorunsal olarak karşımıza çıkmaktadır.

34 Kant, Immanuel: Zum ewigen Frieden, Ein philosophischer Entwurf (1795), Kants Werke, Akademie Textausgabe VIII, Walter de Gruyter, Berlin 1968, s. 381.

35 Kant, 360. 
durduğu iki değerli karşıtlık mantığı sorunsalını akıllara getirmektedir ${ }^{36}$. Buna göre salt insan olmaya bağlı insan hakları ile çoğunluğun iradesini meşru gören demokrasi arasında ortaya çıkan belirgin bir karşıtlığın görmezden gelinmemesi gerekmektedir. Dolayısıyla insan hakları ve demokrasi ilişkisi sorunsalını sadece bir yönüyle ele almak yerine çift taraflı düşünmek küresel anlamda yaşanan insan hakları sorunlarının anlaşılması ve düzeltilmesi adına önemli bir adım olacaktır. Son tahlilde buraya kadar yapmaya çalıştı̆̆ımız analizler bağlamında bazı bulgular elde etmeye ve insan haklarıdemokrasi ilişkisi bağlamında yaşanan açmazların giderilmesine yönelik bazı önerilere ulaşmaya çalışalım.

\section{SONUÇ YERINE}

İnsan haklarının sağlanmasında demokrasinin vazgeçilmez bir rejim olduğunu ileri sürenler ile insan haklarının hayata geçmesinde demokrasinin bozucu bir rol oynayabileceğini savunanlar arasında belirgin bir karşıtlık olduğu anlaşılmaktadır. Bununla birlikte her iki cenahtaki yazarları buzdağının görünen ve görünmeyen kısmını yorumlayanlar olarak da değerlendirmek mümkündür. Öyle ki görünüş itibariyle insan hakları ve demokrasi arasında yurttaşların iradesini önemsemek bakımından bir ilişki olduğunu yadsınmaz bir gerçektir. Diğer taraftan demokrasilerin halkın/yurttaşların iradelerini belirgin bir kitle hâkimiyetine dönüştürme ve bağlamda söz konusu çoğunluğun içinde yer almayanları ihmal etmeleri muhtemel bir durum olarak karşımıza çıkmaktadır.

Araştırmamız bağlamında yer vermeye çalıştığımız analizler demokrasi ile yönetilen ülkelerde yaşanan insan hakları sorunlarının neden kaynaklandığına dair bir takım fikirler sunmaktadır. Buna göre insan hakları özü itibarıyla herkesin doğuştan getirdiği evrensel haklar iken, demokrasilerin çoğunluğun belirlediği bir siyasi iradeyi meşru olarak görmelerinin temel bir sorunsal teşkil ettiği anlaşılmaktadır. Bu bağlamda temel birey hakları olan insan haklarının, demokrasilerin kitle hâkimiyeti ve çoğunluğun iradesinin meşruiyeti anlayışı ile göz ardı edilmesi durumu ile karşılaşılmaktadır. Dolayısıyla insan hakları ile demokrasi arasında yaşanan temel açmazın çoğunluk/kitle ile birey arasında ortaya çıkan karşıtlığ olduğunu ifade edebiliriz. Buna göre demokrasiler halkın çoğunluğunun iradesi ile bir meşruluk kazanırken, tek tek bireylerin iradeleri çoğunluk içinde görmezden gelinebilmektedir. Bu noktada çoğunluğun iradesi/kitle hâkimiyeti ile meşruiyet kazanan demokrasilerde insan hakları özüne uygun olarak sağlanabilir mi?

36 Derrida, Jasques: Platon'un Eczanesi, Çev. Zeynep Direk, Alfa, İstanbul 2016, s. 70. 
diye bir soru akıllara gelmektedir. Diğer bir ifadeyle, buz dağının tamamını göz önünde tutarak, insan hakları ve demokrasi arasındaki mezkûr açmazların giderilmesi mümkün müdür? diye sormak da mümkündür. Son tahlilde insan hakları ve demokrasi arasında olagelen mevcut sorunların/açmazların giderilmesi/iyileştirilmesi bağlamında bazı öneriler sunmaya çalışalım.

Demokrasi ile yönetilen ülkelerde insan haklarının aslına uygun olarak hayata geçirebilmesi için öncelikle demokrasinin yorumladığ 1 ve belirlediği insan hakları anlayışından vazgeçilmesi gerekmektedir. Bunun sağlanabilmesi için de demokrasi ile özdeşleşmiş olan çoğunluğun yönetimi anlayışından vazgeçilmesi, toplumdaki bütün bireylerin ve farkl1lıkların (etnik, dini, mezhepsel vb.) eşit bir biçimde korunup gözetilmesi gerekmektedir. Demokratik rejimlerin söz konusu dönüşümü gerçekleştirebilmesi ile birlikte insan haklarının sağlanmasında demokrasinin önemli bir rol oynayabileceğini iddia etmek mümkün olacaktır. Bu bağlamda demokrasinin meşru gördüğü kadar uygulanan insan hakları düşüncesi yerine insan haklarını toplumda yaşayan bütün bireyler için eşit bir biçimde hayata geçirmek için demokrasiyi motor bir güç olarak belirlemek yerinde olacaktır. Diğer bir ifadeyle temel amacin demokrasinin işlevselliği olan bir toplum anlayışı yerine insan haklarını gerçekleştirmek ve hayata geçirmenin temel amaç olduğu bir topluma doğru evrilmek önemli bir adım olacaktır. Buna göre insan haklarının demokrasi kurumu altında konumlandırılmasından ziyade, demokrasinin en üst değer olan insan hakları altında konumlandırılması anlayışının yaygınlaştırılması gerekmektedir. Söz konusu anlayışın gerçekleştirilebilmesi için temel olarak demokrasiyi asli amaç olan insan haklarının sağlanmasının bir arac1/yolu olacak şekilde belirlemek önem arz etmektedir.

Söz konusu anlayışın hayata geçirilmesi ile birlikte öncelikle siyasi partilerin seçim dönemlerinde halkın oyunu alabilmek adına başvurabileceği insan hakları ihlallerinin önüne geçilebilecektir. Bununla birlikte demokratik yönetimlerin çoğunluğu temsil ederek azınlıkları ve farklılıkları görmezden gelmesi, ya da çoğunluğun faydası için onları baskı altına alması, anlayışının önlenebilmesinin yolu açılmış olacaktır. Böylelikle sadece çok partilik, seçimlerde herkesin oy hakkının olması ve çoğunluğu elde edenin yönetimde söz sahibi olması gibi tutumlar olarak düşünülen demokrasi anlayışı genişleyerek/dönüşerek insan haklarını sağlayıcı bir mekanizmaya evrilmiş olacaktır. Şu halde insan haklarının sağlanması bakımından en fazla oyu alan partinin politik gücü ele geçirdiği ve kendisini iktidara taşıan kitleyi/grubu memnun edici politikalar icra ettiği anlayışından vazgeçilmesi elzem görünmektedir. 
Siyasi partilerin kendilerini iktidara taşıyan kitleye verilen sözleri yerine getirmek ve onları memnun ederek sonraki seçimlerde yine onların kendilerine oy vermelerini sağlamak için girişecekleri politikalar insan haklarına ters düşebilmektedir. Öyle ki insan hakları iktidarı elinde bulunduran siyasi gücün karar verme mekanizmasına dönüştürülemeyecek derecede insanın temel/kadim haklarıdır. Şu halde bu haklar belli bir kitlenin ya da grubun hakları olmanın ötesinde bireyin haklarıdır. Demokrasilerin de o ülkede yaşayan herkesin tek tek insan haklarını sağlayıcı bir mekanizmaya dönüşmesi yerinde olacaktır. Ancak demokrasinin öncelendiği ve insan haklarının demokrasinin meşruiyetine ve karar verme mekanizmasına bırakılması devam ettiği sürece söz konusu sorunların yaşanması kaçınılmaz olarak devam edecektir. Bunun önüne geçebilmek için öncelikle insan hakları demokrasi ilişkilerinde insan haklarının öncelenmesi, demokrasinin; söz konusu hakların prensiplerine göre şekillenmesi gerekmektedir. Böylelikle insan haklarına dayalı demokratik yönetimlerin hakları sağlayıcı birer mekanizmaya dönüşmesi sağlanmış olacaktır.

İnsan hakları ve demokrasi ilişkisi bakımından her iki anlayışın özüne uygun bir tutum benimsenmemesinden kaynaklanan birtakım sorunların yaşandığı anlaşılmaktadır. Küresel anlamda yaşanan insan hakları ihlallerinin temel nedenlerinden birinin de insan haklarının demokratik karar alma uğruna söz ardı edilmesi olduğunu ifade etmemiz mümkündür. Her iki anlayışın/kavramın aralarında daha sağlıklı bir bağın oluşması adına insan hakları ve demokrasi eğitimlerinde bazı iyileştirilmelere gidilmesi önemli bir adım olacaktır. Bu çerçevede demokrasiyi önceleyen ve insan haklarını demokrasinin altında konumlandıran bir eğitim anlayışından vazgeçilerek, insan haklarının temel/çatı değer olduğu hususunda eğitimcilerin bilinçlenmesi gerekmektedir. Aynı zamanda insan haklarını ikinci planda ele alan, sözgelimi "Demokrasi ve İnsan Hakları" ya da "Vatandaşlık ve İnsan Hakları" gibi, derslerin ve ders kitaplarının yeniden gözden geçirilerek, insan haklarını aslına uygun olarak çocukların/gençlerin eğitilmesi gerekmektedir. Şu halde insan hakları insanlığın en üst değeri olduğundan farklı kavramlarla ilişkilendirmeden salt İnsan Hakları adı altında eğitiminin icra edilmesi yerinde bir tutum olacaktır. Söz konusu pedagojik tutumun gerçekleştirilmesi ile birlikte demokrasi ve insan hakları arasında kurulan kavram kargaşasının önlenmesinin yolu açılmış olacaktır. Bununla birlikte insan haklarının sağlanmasında demokratik rejimlerin niçin bozucu bir etki yaptığının aydınlatılması ve söz konusu bozucu etkinin önlenmesi adına da önemli bir kazanım sağlayabilecektir. 


\section{KAYNAKÇA}

Alexy, R.: "Die Institutionalisierung der Menschenrechte im demokratischen Verfassungsstaat", Philosophie der Menschenrechte, ed. Stefan Gosepath, Georg Lohmann, Suhrkamp Verlag, Frankfurt am Main 1998, s. 244-264.

Atiker, E.: "İnsan Hakları Üzerine... Bir Yöntem Denemesi”, Sosyoloji Dergisi, 3/5, 1999, s. 93-110.

Bingöl, O.: "70. Yıldönümünde İnsan Haklarını Yeniden Düşünmek", Mavi Atlas, Çağdaş Felsefe Tartışmaları Özel Sayısı, Aralık 2018, s. 63-76.

Böckenförde, E.-W.: "Ist Demokratie eine notwendige Forderung der Menschenrechte?", Philosophie der Menschenrechte, ed. Stefan Gosepath, Georg Lohmann, Suhrkamp Verlag, Frankfurt am Main 1998, s. 233-243.

Can, N.: Siyaset Felsefesi Problemleri, Elis Yay., Ankara 2005.

Çüçen, A. K.: İnsan Hakları, Sentez Yay., Ankara 2013.

Derrida, J.: Platon'un Eczanesi, (Çev. Zeynep Direk), Alfa, İstanbul 2016.

Dworkin, R.: "Freiheit, Selbstregierung und der Wille des Volkes", Philosophie der Menschenrechte, ed. Stefan Gosepath, Georg Lohmann, Suhrkamp Verlag, Frankfurt am Main 1998, s. 292-309.

Erdoğan, M.: Anayasal Demokrasi, Siyasal Kitabevi, Ankara 2004.

Fox, G. H.: Humanitarian Occupation, Cambridge University Press, Cambridge 2008,

Geis, A.: "Diagnose: Doppelbefund - Ursache ungeklärt? Die Kontroverse um den demokratischen Frieden", Politische Vierteljahresschrift, 42 (2), 2001, s. 282-298.

Gosepath, S.: "Universalität der Menschenrechte - Ein Erklärungsansatz". Gelten Menschenrechte universal? Begründungen und Infragestellungen, ed. Günter Nooke, Georg Lohmann, Gerhard Wahlers, Herder, Freiburg 2008, s. 195-203.

Greenwald, G.: Saklanacak Yer Yok, (Çev. Türkan Çolak), Profil Yay., İstanbul 2015.

Hamm, B.: Menschenrechte Ein Grundlagenbuch, Springer Verlag, Opladen 2003, 
Kant, I.: Zum ewigen Frieden, Ein philosophischer Entwurf (1795), Kants Werke, Akademie Textausgabe VIII, Walter de Gruyter, Berlin 1968, s. 341-386.

Kuçuradi, İ.: İnsan Hakları: Kavramları ve Sorunları, Türkiye Felsefe Kurumu, Ankara 2016.

Ladwig, B.: “Offene Grenzen Als Gebot Der Gerechtigkeit?", Migration Und Ethik, ed. Andreas Cassee, Anna Goppel, Mentis Verlag, Münster 2012.

Menke, C./Pollmann, A.: Philosophie der Menschenrechte zur Einführung, Junius Verlag, Hamburg 2007.

Nida-Rümelin, J.: Demokratie will Öffentlichkeit, Die Zeit, 16.12.2010: http://www.zeit.de/2010/51/Wikileaks/komplettansicht, Erişim Tarihi: 01.03.2019.

Özek, Ç.: "İnsan Hakları Kavramında Yeni Anlayış ve Sınırlamalar", İstanbul Üniversitesi Hukuk Fakültesi Mecmuas1, 60/1-2, 2002, s. 135160.

Sirleschtov, A./ Monath, H./ Woratschka, R.: "Seehofer bedauert Suizid von abgeschobenem Afghanen": https://www.tagesspiegel.de/politik/ asylpolitik-seehofer-bedauert-suizid-von-abgeschobenemafghanen/22789716.html, Erişim Tarihi: 01.03.2019.

Tepe, H.: "Sosyal Haklar ve İnsan Haklarn: Sosyal ve Ekonomik Haklar Olmadan İnsan Hakları Korunabilir mi?", Uluslararası Sosyal Haklar Sempozyumu Bildiriler, ed. Nergiz Mütevellioğlu, Mehmet Zanbak, Belediye-İş, Ankara 2009, s. 97-104.

Tomasevski, K.: Development Aid and Human Rights Revisited, Pinter, New York 1993.

Touraine, A.: Demokrasi Nedir?, (Çev. Olcay Kunal), Yapı Kredi Yayınları, İstanbul 2002.

Tosun, G. E.: "Birleştirici Demokrasi Devlet-Sivil Toplum İlişkisinin Yeniden Yapılandırılması İçin Bir Aracı Olabilir mi?", Sivil Toplum ve Demokrasi, ed. Lütfi Sunar, Kaknüs Yayınları, İstanbul 2005, s. 23-54.

Tüzün, G.: Ortaöğretim Demokrasi ve İnsan Hakları Ders Kitabı, Ada Matbaacılık, Ankara 2018.

Üçbaş, T.: Demokrasi ve İnsan Hakları Liseler İçin Ders Kitabı, Fil Yayınevi, İstanbul 2010. 
Yeşilçayır, C.: Ebedi Barış, Pax Romanadan Birleşmiş Milletlere, Tezkire Yay., İstanbul 2017.

Yeşilçayır, C.: "İnsan Haklarının Aydınlatılmasında Felsefi Bilginin Önemi”, Kayg1 Uludağ Üniversitesi Fen-Edebiyat Fakültesi Felsefe Dergisi, 31/2, 2018, s. 239-261.

Yeşilçayır, C.: "Sığınmacılar Hakkındaki Ön Kabulleri Belirleyen Etmenler Üzerine Eleştirel Bir Değerlendirme", Kutadgubilig Felsefe-Bilim Araştırmaları 32, 2016, s. 121-138.

Wellmer, A.: "Menschenrechte und Demokratie", Philosophie der Menschenrechte, ed. Stefan Gosepath, Georg Lohmann, Suhrkamp Verlag, Frankfurt am Main 1998, s. 265-291. 
